\title{
AS SOBREVIVÊNCIAS DOS SIGNOS, A MEMÓRIA INVOLUNTÁRIA DO ESTRANGEIRO E O ESPAÇO URBANO EM RUÍNAS
}

\author{
Cacio José Ferreira* \\ Norival Bottos Júnior
}

RESUMO: Este artigo tem a intenção de refletir sobre a qualidade e a pluralidade dos signos emitidos nos quatro primeiros romances de Milton Hatoum, Relato de um certo Oriente (2014), Dois irmãos, (2007), Órfãos do eldorado, (2008), Cinzas do Norte (2012). Partindo dos pressupostos teóricos de Gilles Deleuze e Félix Guattari sobre os modos de interpretação dos signos de memória: os signos de amor, sensíveis, mundanidade e de arte, este último, responsável por reunir as outras formas de signos. O objetivo é tentar evidenciar de que modo as modulações de produção de intensidade e individuação não segmentadas em binarismos possibilitam entender que na obra do escritor amazonense o tema não é a memória, mas as sobrevivências das imagens traumáticas, os sintomas da violência, os fantasmas e as sobrevivências de signos. Os signos de amor, por exemplo, além de ligarem-se aos signos de arte, nos permitem interpretar como sobrevivem os amores incestuosos, tema recorrente em Milton Hatoum. Enfim, estas novas formas de individuação e produção de subjetividades não retornam, no complexo jogo de ruínas na forma de memória, mas sim, segundo assevera Gilles Deleuze, em práticas de produção de signos que afetam e se deixam afetar por outras subjetividades plurais. O resultado é que a apreensão desses signos nos romances de Milton Hatoum não pode ir além daquilo que se encerra dentro dos próprios signos que se repetem, repelem-se e dialogam entre si incessantemente.

PALAVRAS-CHAVE: Signos. Sintomas. Fantasmas. Memória. Amazonas.

\footnotetext{
* Professor da Universidade Federal do Amazonas (Ufam). Mestre em Literatura pela UnB. Doutorando em Estudos Literários Comparados (UnB). Membro dos seguintes grupos de pesquisa CNPq: Estudos Osmanianos: arquivo, obra, campo literário (UnB), Estudos Japoneses (UFAM), Observatório de ensino de línguas (UFAM) e Estudos Asiáticos (UnB).

${ }^{* *}$ Doutor em Letras e Linguística pela Universidade Federal de Goiás (UFG).
} 


\section{Introdução}

Para Gilles Deleuze e Félix Guattari (2003), a memória ocupa um lugar secundário, principalmente em se tratando de narrativas cujo eixo central seria o próprio recurso da escrita memorialística. A busca pela identidade e pela representação do passado corresponderia menos à unificação das partes fragmentadas que faltam a todo recurso memorialístico e mais a ver com a afirmação de uma diferença irremediável no ato de abandonar a retórica da memória em favor do caráter terrorista da arte voltada para a decifração dos signos de uma realidade viva e paradoxalmente inapreensível ${ }^{1}$. De acordo com Gilles Deleuze (2003), a ilusão de objetivismo que reside por trás da ideia do testemunho não funciona quando se interpreta os signos separadamente, para ele não se trata de compor uma narrativa que dê conta da representação do que aconteceu em algum momento do passado ou do caráter fragmentário desse passado, mas sim da narrativa como o acontecimento em si. Diz ele:

É decepcionante, por natureza, uma literatura que interpreta os signos relacionando-os com objetos designáveis (observação e descrição), que se cerca de garantias pseudo objetivas do testemunho e da comunicação (conversa, pesquisa), que confunde o sentido com significações inteligíveis, explícitas e formuladas. (DELEUZE, 2003, p. 31)

Gilles Deleuze e Félix Guattari (2012) chamam atenção inicialmente para o fato de que o que constitui a riqueza da obra máxima de Marcel Proust, Em busca do tempo perdido (2016), não é a memória, nem mesmo a memória involuntária, mas antes, um amplo jogo de sistemas de signos que o romancista francês elabora segundo a ideia de que os signos representam paradigmas de interpretação plurissignificativos e que precisam ser interpretados de acordo com a multiplicidade significativa a que estão envolvidos em relação à matéria a que se destinam, ou dito de outro modo, à decifração do visível, do legível ou mesmo do que permanece invisível. Analisando o conceito de signos de Gilles Deleuze, Roberto

1 "A voz situa-se, precisamente, entre a animalidade e a linguagem, entre a natureza e a história. A questão da ética e da política, (...) ocupará o lugar da Voz” (CASTRO, 2016, p. 16). 
Machado observa:

Os signos constituem tanto a unidade quanto a pluralidade da $R e$ cherche. Unidade no sentido em que todos os "domínios", "campos", "mundos" apresentados ou criados por Proust formam sistemas de signos emitidos por pessoas, por objetos, por matérias. Tudo é signo. Mas, por outro lado, os signos são heterogêneos. O sistema que constitui a obra é pluralista no sentido em que os signos não são do mesmo tipo, do mesmo gênero: não têm a mesma relação com a matéria em que estão inscritos, não são emitidos do mesmo modo, não têm o mesmo efeito sobre o intérprete, não têm a mesma relação com o sentido, com as faculdades que os interpretam, com as estruturas temporais neles implicadas, com a essência. (MACHADO, 2010, p. 195)

O que pode constituir a riqueza do recurso da memória para a arte, de acordo com o pensamento Gilles Deleuze e Félix Guattari (2014) não seria a memória em si, mas antes, as amplas possibilidades de se dispor dos mais diversos sistemas de signos na criação de estruturas heterogêneas, tanto do ponto de vista da onisciência quanto da parcialidade, tanto do ponto de vista espacial quanto temporal.

Para os narradores donos de uma escrita essencialmente baseada no recurso da memória, como Em busca do tempo perdido (2016), de Marcel Proust, que narra em primeira pessoa e cujo narrador mantém relação muito próxima com as experiências vividas pelo próprio autor e, portanto, mais próximas da experiência estética, ética e moral do próprio leitor, como afirma Wayne Booth (1980) que também chama a atenção para a existência de um "autor implícito". Para ele:

O autor implícito pode estar mais ou menos distante do leitor. [...] Sob o ponto de vista do autor, uma boa leitura de seu livro tem de eliminar toda a distância entre as normas essenciais do seu autor implícito e as normas do leitor postulado. [...] o mais importante destes tipos de distanciamento é, talvez, o que fica entre o narrador falível e o autor implícito que se faz acompanhar pelo seu leitor no seu juízo sobre o narrador. Se se discute ponto de vista com o fim de descobrir a sua relação com efeitos literários, então as qualidades morais e intelectuais no narrador não podem, certamente, deixar de ser mais importantes para o nosso juízo do que o facto de ele ser referido como um "eu" ou "ele", ou de ser privilegiado ou limitado. (BOOTH, 1980, p. 173) 
Agindo sob as condições determinadas por um narrador que, por falar por "si mesmo" seria mais confiável do que um narrador onisciente, espectral, que outorga a voz que fala para um "outro" indeterminado, mas ainda assim dotado de capacidades éticas temporais:

[...] a favor da distinção entre identidade do si e identidade do mesmo a partir do uso que fazemos dessa noção nos contextos em que duas espécies de identidades deixam de sobrepor-se a ponto de se dissociarem inteiramente, pondo de algum modo a nu a ipseidade do si sem o suporte de mesmidade. Na verdade, é outro modelo de permanência no tempo [...]. É o da palavra cumprida na fidelidade à palavra dada, [...] a palavra expressa uma manutenção de si que não se deixa inscrever na dimensão do algo em geral, mas unicamente na de quem. [...] Essa justificação ética, tomada como tal, desenrola suas próprias implicações temporais, a saber, a modalidade de permanência do tempo [...]. (RICOEUR, 2014, p. 124-125, grifos do autor)

De acordo com Gilles Deleuze (2003), não há espaço, na contemporaneidade, para pensamentos que não levem em conta a produção ininterrupta de produção de devires no lugar das clássicas dicotomias binárias de oposição. Para os ficcionistas contemporâneos, o inatual estaria relacionado com o hiper-realismo do cotidiano em detrimento de uma ética cada vez mais restrita a certos grupos privilegiados. Nesse caso, exigir-se-ia um tipo de narração que estivesse apta a refletir sobre o mundo contemporâneo como uma realidade fraturada pela ausência de uma ética universal e irrestrita. Na narrativa em primeira pessoa, estabelecer-se-ia uma relação diferenciada com os signos. Para escritores que pertencem às margens do mundo ocidental, ou seja, que experimentam a ética como o inatual de que trata Giorgio Agamben (2014), como é o caso, por exemplo, de Milton Hatoum, a estrutura dos signos representam a busca pelo aprendizado e a progressão da narrativa depende do modo como esses signos serão capazes de expandir- se em espaços heterogêneos e repletos de pluralidade, noção que exigiria uma visão aperspectivista.

\section{A representação pelos signos do mundo em ruínas nas obras de Milton Hatoum}

Ao contrário de uma narrativa cujo objetivo seja fazer valer o papel da memória, o 
ato de narrar busca partir de um "eu” deslocado do centro para as margens, tornando-se, desse modo, um puro devir. O tempo e o espaço linear desaparecem, o tempo vivido opera na interioridade sempre última de um narrador cujo único propósito é o de anular-se a si mesmo, de tornar-se anacrônico dentro de seu próprio tempo histórico, um eterno paradoxo do ontem, pois ser anacrônico não significa colocar-se fora do tempo, mas fazer fluir todos os tempos num mesmo regime de signos e fluxos de consciência.

Voltar-se para sua própria voz, elevá-la ao paroxismo do vazio por trás da individualidade resulta no trabalho de tecer uma escritura baseada na existência do ser do homem no mundo, mas uma experiência que precisa ser interpretada, necessitando, assim, fazer de sua própria história um jogo de interpretações, ou seja, trata-se, antes de tudo, de uma tarefa de interpretação de signos, de apreensão da verdade dos signos.

De acordo com Gilles Deleuze (2003, p.18), trabalhar com os signos consiste em mostrar como é impossível ter acesso ao passado puro e, mesmo assim, diante da impossibilidade de resgatar o passado através dos olhos e da linguagem do personagem-narrador, o ato de narrar permite que este narrador habite, simultaneamente, entre o vazio e a impossibilidade de afirmar um “eu”. Além disso, ao mesmo tempo, há a necessidade de sempre retornar a esse "eu”, voltar a ele como quem busca salvar-se de si mesmo:

Há uma ambivalência que sempre permanece como uma possibilidade da memória em todos os signos em que ela intervém (daí a inferioridade desses signos). É que a própria Memória implica a estranha contradição entre a sobrevivência e o nada, a dolorosa síntese da sobrevivência e do nada. (DELEUZE, 2003, p. 19)

Os signos de mundanidade dizem respeito ao caráter heterogêneo que emana de certas "famílias espirituais" às quais pertencem os diferentes grupos sociais. São grupos que se diferenciam por se constituírem de famílias intelectuais, que mantêm entre si certas crenças, certos códigos de conduta sociais que fazem com que os signos produzidos por eles emanem aquilo que são. Isto significa dizer que os signos de mundanidade expõem, através da memória, um devir que a enunciação de um "eu” expõe ou acredita expor a si mesmo. Não pode ser entendido senão como o próprio abandono a um grupo ou família de signos 
bem específicos e que não podem funcionar em outras circunstâncias.

Desse modo, é possível notar que em Dois Irmãos (2007, p.51), os gazais de Abbas, recitados por Halim ainda jovem, no restaurante Biblos, de propriedade de seu futuro sogro, Galib, serviam como um signo mundano de união familiar ou de um grupo específico de pessoas que compreendem o conteúdo e o valor dos gazais. Os signos de mundanidade nada dizem se não estiverem relacionados com os signos capazes de conectar os fios narrativos que os signos de mundanidade deixam pelo caminho. Um dos signos mais relevantes segundo Gilles Deleuze (2003) é denominado por ele como os signos de amor. Isto acontece porque os signos de amor são secretos para aquele que ama. A tarefa de decifrar os signos de um mundo obscuro para o amador torna-se seu maior objetivo. O ser amado emite signos cujo amador nunca pode ter acesso, não pode decifrá-lo. O amador torna-se vítima do processo de tentar compreender o sistema de signos que o amado emite, sem, contudo, ter acesso a eles, o que leva o amador a sentir ciúmes do amado. Embora não possa se esquivar nem do ciúme nem da tarefa de compreender o que estes signos querem dizer, a decifração por si mesma se torna, desse modo, o objetivo daquele que ama:

Apaixonar-se é individualizar alguém pelos signos que traz consigo ou emite. É tornar-se sensível a esses signos, apreendê-los [...]. É possível que a amizade se nutra de observação e de conversa, mas o amor nasce e se alimenta de interpretação silenciosa. $O$ ser amado aparece como um signo, uma "alma": exprime um mundo possível, desconhecido de nós. O amado implica, envolve, aprisiona um mundo, que é preciso decifrar, isto é, interpretar. [...]. Amar é procurar explicar, desenvolver esses mundos desconhecidos que permanecem envolvidos no amado. (DELEUZE, 2003, p. 7 - grifos do autor)

Nas obras de Milton Hatoum, de modo geral, os signos de amor transformam- se, quase sempre, em signos de ciúme. Os signos de ciúme também deixam desvelar um tema bastante caro ao romancista amazonense, o do amor proibido, do amor incestuoso, ou seja, os signos de amor marcam a intensidade da narrativa através do ciúme e das paixões proibidas. Os signos de amor são convertidos quase que naturalmente, nessas narrativas, em signos de ciúme. O ciúme é umas das características que o emissor de signos de amor deve 
emitir porque há sempre o momento em que o amador descobre a impossibilidade de decifrar os signos emitidos pelo ser amado. Nesse ponto, histórias de amor proibidos ganham em intensidade. Para Deleuze,

O ciúme vai mais longe na apreensão e na interpretação dos signos. Ele é a destinação do amor, sua finalidade. De fato, é inevitável que os signos de um ser amado, desde que "expliquemos", revelem-se mentirosos: dirigidos a nós, aplicados a nós, eles exprimem, entretanto, mundos que nos excluem e que o amado não quer, não pode nos revelar. Não em virtude de má vontade particular do amado, mas em razão de uma contradição mais profunda, que provém da natureza do amor e da situação geral do ser amado. [...]. O intérprete dos signos amorosos é necessariamente um intérprete de mentiras. O seu destino está contido no lema "Amar sem ser amado". (DELEUZE, 2003, pp. 8-9 - grifos do autor)

No caso do romance Dois Irmãos (2007), há uma profusão de personagens que emitem signos de amor e ciúme: o patriarca Halim sente ciúmes da relação entre sua esposa Zana e os dois filhos gêmeos, especialmente de Omar; Zana, por sua vez, sente ciúmes das namoradas de Omar e da esposa de Yaqub. Os dois irmãos sentem ciúme doentio um pelo outro, a ponto de destruírem toda a estrutura familiar em busca da decifração do amor materno. Yaqub sente que a mãe, Zana, ama de modo mais intenso o outro irmão, Omar, e talvez este seja o motivo principal para o embate entre os dois, o ódio que os dois irmãos irão compartilhar até a destruição total da família. Omar também sente ciúmes do irmão por outros motivos, pois coube a Yaqub o privilégio de progredir financeira e socialmente.

Em Órfãos do Eldorado (2008), o tema da decifração dos signos de amor que acaba culminando numa ampla rede de ciúmes pode ser considerado um dos temas mais relevantes da obra. Toda a narrativa converge para a paixão desmedida que o narrador-protagonista, Arminto Cordovil, sente por Dinaura, uma índia misteriosa que desaparece sem deixar vestígios quando os dois estão noivos. O desaparecimento de Dinaura provoca um redemoinho na vida de Arminto Cordovil. Incapaz de cuidar dos negócios da família, aos poucos Arminto vê sua fortuna desaparecer enquanto empreende inúmeras buscas pelo paradeiro de Dinaura.

Em Cinzas do Norte (2012), os signos de amor também precisam ser decifrados pela 
intensidade dos signos de ciúme que os personagens que amam emitem. O ciúme despertado entre Jano, o magnata e Ranulfo, um desempregado sonhador e boêmio, marca também a ruína familiar neste romance. Porém, como deixa claro no final, fica-se sabendo que Mundo não é filho de nenhum dos dois, mas do artista Arana, de quem Mundo acaba herdando a inclinação para a arte. Também relevantes são os signos de qualidades sensíveis, a partir deles os dramas familiares se conjugam com o mundo das ruínas físicas que os cercam. Para Gilles Deleuze,

Uma qualidade sensível nos proporciona uma estranha alegria, ao mesmo tempo que nos transmite uma espécie de imperativo. Uma vez experimentada, a qualidade não aparece mais como uma propriedade do objeto que a possui no momento, mas como o signo de um objeto completamente diferente, que devemos tentar decifrar através de um esforço sempre sujeito ao fracasso. Tudo se passa como se a qualidade envolvesse, mantivesse aprisionada, a alma de um objeto diferente daquele que ele agora designa. (DELEUZE, 2008, pp. 1011 - grifos do autor)

Os signos sensíveis engendram um espaçamento e uma temporalidade outra na presença dos objetos que emitem. Nos signos sensíveis, há sempre a presença de algo que está ausente. Não se trata, porém, de uma memória involuntária que emerge como configuração artística, mas antes, como um rastro. No sentido que Jacques Derrida (2003) dá ao termo.

Os dramas familiares estão ligados à cidade de Manaus, de modo intrínseco, é o mundo da oralidade que inicialmente atrai os narradores. Ficção e realidade se misturam nas histórias orais contadas dentro do núcleo familiar. Os signos criam através da oralidade, uma relação nem sempre clara entre os signos e os objetos, às coisas. De acordo com o autor, a narrativa é construída pelo núcleo familiar:

Eu parto da família. [...] O núcleo familiar é importante porque faz parte de uma história local. A literatura fala do particular porque faz parte de uma história local. A literatura sobre generalidade não aprofunda muita coisa. Então, minha vivência na família árabe-amazônica de Dois Irmãos foi importantíssima. Não só a minha família, mas a dos vizinhos, dos caboclos, dos empregados, dos pescadores. Eu saía muito para pescar em Manaus com meu avô, que era um 
grande contador de histórias. Então, meu primeiro livro foi "ouvido". (HATOUM, 2000, p. 13)

Os quatro romances analisados neste trabalho estão marcados por essas trilhas que os signos sensíveis emitem de maneira fragmentária, cabendo, assim, aos narradores tornar visível o tempo da metamorfose dos objetos, temporalidades desconexas, mas que, mesmo assim, formam uma narrativa própria para cada personagem. Este rebaixamento da memória involuntária em nome dos signos sensíveis prevalece ao longo do extraordinário conjunto da obra do escritor amazonense.

O primeiro romance de Milton Hatoum, Relato de um certo Oriente (2008) traz uma personagem feminina cujos recursos estilísticos são mais abundantes que aos outros narradores, embora todos eles compartilhem uma certa noção de intensidade estética, pois todos são de algum modo personagens que precisam refletir e escrever sobre o que se passou, precisam retomar as pontas soltas que foram deixadas na forma de rastros do passado. Nesse primeiro romance, cujo título remete a uma região oriental ainda desconhecida, ou mesmo ambígua, cuja própria exuberância do título deixa antever a metáfora de uma região ignota. Essa região jamais conhecida, de fato vem acompanhada pela paixão que a linguagem evoca pela capacidade de alegrar-se com a beleza dos objetos sensíveis.

Parece que é exatamente isso o que expressa a descrição do momento em que o patriarca da família árabe muçulmana leva a narradora inominada para conhecer o restaurante da família "A Parisiense” em seus recônditos, além de ensinar-lhe as primeiras lições da língua árabe que, aliás, não é falada em casa. Gradualmente, a narradora trava contato com essa língua desconhecida, cuja descoberta desconcerta-a porque torna evidente a falsa ideia de que os signos estão presos às coisas que representam. Para a narradora inominada do romance, entrar em contato com essa língua estrangeira significa tirar o "pó" que o uso cotidiano dá às palavras:

As primeiras lições foram passeios para desvendar os recantos desabitados da Parisiense, os quartos e cubículos iluminados parcialmente por claraboias: o corpo morto da arquitetura. Sentia medo ao entrar naqueles lugares, e não entendia por que o contato inicial com 
um idioma inaugurava-se com a visita a espaços recônditos. Depois de abrir as portas e acender a luz de cada quarto, ela apontava para um objeto ou soletrava o que parecia estalar no fundo de sua garganta; sílabas, de início embaralhadas, logo eram lapidadas para que eu as repetisse várias vezes. Nenhum objeto escapava dessa perquirição nominativa que incluía mercadorias e objetos pessoais: cadinhos de porcelanas, almofadas bordadas com arabescos, pequenos recipientes de cristal contendo cânfora e benjoim, alcovas, lustres formados de esferas leitosas de vidro, leques da Espanha, tecidos, e uma coleção de frascos de perfume que do almíscar ao âmbar formava uma caravana de odores que eu aspirava enquanto repetia a palavra correta para nomeá-los. [...] Passei cinco ou seis anos exercitando esse jogo especular entre pronúncia e ortografia, distinguindo e peneirando os sons, domando o movimento da mão para representá-los no papel, como se a ponta do lápis fosse um cinzel sulcando com esmero uma lâmina de mármore que aos poucos se povoava de minúsculos seres contorcidos e espiralados que aspiravam à forma dos caracóis, das goivas e cimitarras, de um seio solitário que a língua ao contato com o dorso dos dentes e ajudada por um espasmo fazia jorrar dos lábios entreabertos em peixe Fenício. (HATOUM, 2014, pp. 45-46)

Não é difícil perceber que a interpretação dos signos sensíveis funcionam, geralmente, pela via do excesso, o que sugere pensar que o que transparece em demasia é desacreditado em nome de uma ideia mantida obsessivamente pelos narradores "ilegítimos" (CURY, 2009, p. 47). Há quase sempre uma ideia fixa de algo perdido no passado, uma ideia redentora (CONRAD, 2008) capaz de recompor o sentido do mundo, capaz, de todo modo, de dar conta de uma narrativa que não deixe à mostra suas pontas soltas.

Da linguagem que os signos sensíveis emitem transborda uma estranha fascinação, pois, ao mesmo tempo em que essa ideia fixa toma o lugar dos objetos, deixando para trás tudo o que não diz respeito à própria ideia daquilo que se perdeu definitivamente, ou seja, do mundo que se arruinou, ao mesmo tempo busca-se reconstruir, através da linguagem que fascina e desorienta a multiplicidade de vozes dissonantes e aperspectivistas e que, para Maurice Blanchot, paradoxalmente, residiria na verdadeira causa do fascínio da escrita:

Quem quer que esteja fascinado, pode-se dizer dele que não enxerga nenhum objeto real, nenhuma figura real, pois o que vê não pertence ao mundo da realidade mas ao meio indeterminado da fascinação. [...]. Esse meio da fascinação, onde o que se vê empolga a vista e 
torna-a interminável, onde o olhar se condensa em luz, onde a luz é o fulgor absoluto de um olho que não vê mas não cessa, porém, de ver, porquanto é o nosso próprio olhar no espelho, esse meio é, por excelência, atraente, fascinante: luz que é também o abismo, uma luz onde a pessoa afunda, assustadora e atraente. (BLANCHOT, 2011, p. 24)

Em O que é filosofia? (1993), Gilles Deleuze enfatiza que a memória ocupa um pequeno espaço na arte, especialmente em romancistas que dependem da memória como matéria-prima, como, por exemplo, Marcel Proust. Para o filósofo francês (2003), a finalidade da arte, numa ideia que em grande medida é influenciada por Henry Bergson², é alargar a percepção da noção que temos de espaço e de tempo, sempre que a arte apela para a memória ela está apelando para o surgimento de algo mais importante do que o ato de rememorar pode sugerir. A memória seria, nesse caso, mais uma sugestão, uma evocação do que uma finalidade. A respeito do papel da memória nos romances de Milton Hatoum, Maria Zilda Cury afirma:

O lugar da memória é então recriado pela mediação de vozes fragmentárias, imprecisas e conscientes da impossibilidade de recuperação do vivido. Os processos de composição ficcional adotados não privilegiam qualquer voz, e fazem viver, no espaço narrativo, as memórias de narradores e suas vozes particulares, frequentemente dissonantes - memória como invenção, sem intuito de reconstituição de um pretenso espaço autêntico ou originário. (CURY, 2009, p. 48)

Nesse sentido, sempre que se expressa pelo uso da memória o que se faz é tornarse devir, produzir um devir. Para Gilles Deleuze, substituir a memória pelo devir significa dizer que é o presente e não o passado o ponto nevrálgico. A procura empreendida pelos narradores nos três romances e na novela de Milton Hatoum centra-se no fato de que a memória não é orientada pelo passado, mas pelo aprendizado futuro, através dos signos que se convergem no signo de arte. Todos os outros signos estudados até então convergem para os signos de arte como aprendizado: 
Aprender é relembrar, mas relembrar nada mais é do que aprender, ter um pressentimento. Se, impulsionados pelas etapas sucessivas do aprendizado, não chegássemos à revelação final da arte, permaneceríamos incapazes de compreender a essência, até mesmo de compreender que ela já estava na lembrança involuntária ou na alegria do signo sensível (estaríamos sempre reduzidos a "adiar" o exame das causas). É necessário que todas as etapas conduzam à arte e que atinjamos sua revelação; então tornaremos a descer os níveis, os integraremos na própria obra de arte, identificaremos a essência em suas realizações sucessivas, daremos a cada nível de realização o lugar e o sentido que lhe cabem na obra. Descobriremos, assim, o papel da memória involuntária e as razões desse papel importante, embora secundário, na encarnação das essências. Os paradoxos da memória involuntária se explicam por uma instância mais elevada que ultrapassa a memória, inspira as reminiscências e lhe comunica uma parte de seu segredo. (DELEUZE, 1998, pp. 61-62, grifos do autor)

Em todos os romances de Milton Hatoum percebe-se a imperfeição da memória. Em Cinzas do Norte, Lavo, o narrador e amigo próximo do protagonista, revela sua fome de imaginação enquanto desvela imagens, acontecimentos que, de certo modo, precisam manter-se à margem do mundo "real". É um problema de consciência o que ele enfrenta. As histórias que ele narra surgem como transfiguração de um passado ao qual ele se posiciona apenas como testemunha.

$\mathrm{Na}$ condição de intelectuais marginais, os narradores dessas narrativas procuram tornar inteligível, por meio do testemunho, os processos históricos e culturais que fazem vir à tona o estatuto da subjetividade de um sujeito desubjetivizado, entregue à vida nua, a vida puramente biológica. Em outras palavras, trata-se de narrar a maneira como a violência das instituições falham na tentativa de sobrepujar os diferentes fluxos rizomáticos e os fios narrativos insuspeitos que criaturas anônimas tecem como uma história anacrônica.

Neste sentido, para se pensar um espaço marginal, sobretudo, "oriental" como o mundo amazônico, torna-se necessário ocupar-se da relação com os limites impostos pela linguagem como máquina desarticuladora das normas ditadas pelas máquinas burocráticas. É o problema que cabe ao escritor menor, dono de uma memória imperfeita e cuja tarefa deve ser a de escrever sobre aquele conjunto de elementos que, embora capazes de ser 
reproduzidos historicamente, pertencem ao presente insondável.

A linguagem dos narradores em Milton Hatoum é, nesse sentido, a linguagem do indizível, daquilo que pertence ao mundo desubjetivizado. São as engrenagens que, na linguagem do escritor menor, fazem com que a própria linguagem burocrática transborde para além de seus limites, situando-se, então, para além da economia narrativa de uma obra que exige daquele que pode testemunhar a força do relato. E é este o espaço onde a linguagem torna-se evocação de um puro silêncio. É nesse sentido que o filósofo italiano Giorgio Agamben comenta:

Gilles Deleuze analisou o caráter particular da forma, aproximandoa daquelas expressões que os linguistas definem como agramaticais. [...]. Como sugere Deleuze, que ela [a forma agramatical] abre uma zona de indiscernibilidade entre o sim e o não, o preferível e o não preferido, entre a potência de ser (ou de fazer) e a potência de não ser (ou de não fazer). (AGAMBEN, 2015, p. 28)

Giorgio Agamben chama atenção para o indiscernível que Gilles Deleuze opõe à gramaticalidade, ou melhor, aos limites da gramaticalidade, do significante e do significado, da relação biunívoca que é a base para a linguística e os limites de se pensar para além da biunivocidade linguística, algo que estaria na linha de produção de uma esquizoanálise. É relevante pensar o estatuto do indiscernível porque, tanto para Giorgio Agamben quanto Gilles Deleuze, não pode haver uma memória infalível. O indiscernível supera o alcance da memória porque é o espaço onde se instauram a impessoalidade e a neutralidade de um “eu” que se articula através da palavra escrita. A memória faz emergir este outro "eu”, mas que não deixa de ser impessoal porque um dia fora invocado como uma terceira pessoa sem que, entre ambos, tenha sido possível reconhecer qual a distância verdadeira separavaos ou que, exatamente, os separava no momento mesmo da evocação, seja a memória voluntária como no caso de Milton Hatoum, ou numa operação mais adversa, como a memória involuntária de um Marcel Proust. Veja-se a seguinte citação de Gilles Deleuze:

Em que consiste a unidade de La recherche du temps perdu? Sabemos ao menos que ela não consiste na memória, nem tampouco na lembrança, ainda que involuntária. O essencial da Recherche, a busca, não 
é simplesmente um esforço de recordação, uma exploração da memória: a palavra deve ser tomada em sentido preciso, como na expressão "busca da verdade". Por outro lado, o tempo perdido não é simplesmente o tempo passado; é também o tempo que se perde, como na expressão “perder tempo". É certo que a memória intervém como um meio de busca, mas não é o mais profundo; e o tempo passado intervém como uma estrutura do tempo, mas não é a estrutura mais profunda. Os campanários de Martinville e a pequena frase musical de Vinteuil, que não trazem à memória nenhuma lembrança, nenhuma ressurreição do passado, têm, para Proust, muito mais importância do que a madeleine e o calçamento de Veneza, que dependem da memória, e, por isso, remetem ainda a uma "explicação material".

Não se trata de uma exposição da memória involuntária, mas do relato de um aprendizado - mais precisamente, do aprendizado de um homem de letras. (DELEUZE, 2003, p. 3 - grifos do autor)

Para o homem de letras, para um pensador das margens, por exemplo, a memória não é o material mais importante, nem mesmo o tempo puro da arte, mas antes, o que se pode denunciar como arbitrária e tendenciosa a atitude de posicionar-se deliberadamente no presente da escrita, ou dito de outro modo, tornar perceptível como pode ser falsa a distância marcada pela lembrança ou pela memória involuntária. É uma distância antes de tudo, portanto sempre apta a falhar, a provocar imprecisões. A memória não é como uma essência, mas uma particularidade que traz à tona aquilo que permaneceria, contudo, ocultado, não fosse o esforço de buscar através dos destroços das recordações algo parecido com uma fascinação.

Milton Hatoum é hábil em exilar a palavra, tudo parece começar pelo meio, porém, sem um início ou um fim aparente, parece que nestas narrativas tudo se encaminha para a auto-aniquilação. É uma narrativa sem raízes, sem dúvida, capaz apenas de evocar, ora o horror da existência nas margens do Ocidente ora o horror de fazer apagar-se junto às ruínas da linguagem que esse mundo evoca. Esta última característica reduz o papel da memória na economia narrativa. Cabe aos signos e ao estranho pudor de seu desvelamento os diferentes regimes de signos que dão forma e relevo ao destino das personagens que habitam o mundo amazônico na condição de estrangeiros em sua própria terra. Sobre essa noção diferenciada de estrangeiro, Edgar Morin argumenta que: 
O "estrangeiro", em que, de impensadas distâncias, somos chamados a responder. Mas responder ao estrangeiro que nos dirige a palavra não significa desvelar sua identidade, desvelar-lhe o rosto. Tampouco fazer com que ele se volte, deixando de nos dar as costas para se conceder plenamente a nosso olhar. Ao contrário: responder significa continuar a vê-lo de costas, aceitando a obliquidade de sua presença, sem que seja possível identificá-la. (MORIN, 2004, p. 10)

No Amazonas, em Manaus, os signos de mundanidade, os signos sensíveis, os signos de amor e, por fim, os signos de arte atravessam o regime dos ciclos das estações equatoriais: rios e seus afluentes, cidades e a vida selvagem, brancos e indígenas. Os signos sensíveis respiram os diferentes aromas, confundem suas paragens, tornam-se por fim, signos de arte. Esse estilhaçamento de signos tão variados como os signos sensíveis e os signos de amor estão presentes em todos os romances de Milton Hatoum na forma de práticas discursivas e, sobretudo, sociais (FOUCAULT, 1987).

O mundo de Milton Hatoum certamente é o Amazonas, mas um Amazonas reduzido a sistemas de signos destinados a evocar o fracasso e o vazio pela linguagem. Por isto, retroceder à memória, ao passado glorioso, ao passado arruinado pela ganância desenfreada significa tocar o próprio vazio da experiência da linguagem literária, ou seja, puro desejo de perder-se na linguagem e deixar-se ser levado por ela, como no leito de um rio extenso como o Amazonas.

Um escritor de rios, tal como Joseph Conrad, Milton Hatoum não pode conceber uma literatura arraigada, fixa, seu lugar ou, melhor dizendo, seu não-lugar é o espaço onde os homens chegam e de onde tornam a partir, lugar de estrangeiros, de signos que atuam como potência de ser para-ir-além, para não esquecer o Oriente para sempre perdido, para não esquecer o Eldorado, ou mesmo responder ao estrangeiro, o Outro, como um si mesmo, um desvelamento do ser através dos signos de arte. Nas palavras de Maurice Blanchot a respeito da obra de Marcel Proust:

As marcas: traços não daquilo que aconteceu, mas do que jamais se passou. E eis aqui o que nos distancia das lembranças, lembranças involuntárias, recuperadas gloriosamente e capazes de afastar a 
morte através da arte ressuscitada. (BLANCHOT, 2011, p. 38)

Nos romances de Milton Hatoum, os espaços geográficos de Manaus fazem com que seus personagens gravitem sempre entre dois extremos: de um lado, a lembrança física do passado glorioso, a opulência dos edifícios, dos teatros, os casarões de fazendeiros, as praças de inspiração europeia, ou seja, todo um conjunto arquitetônico construído durante a belle époque no centro da cidade; de outro, a miséria dos casebres da chamada cidade flutuante, palafitas construídas à beira do rio Negro, da violência e da extrema pobreza dos conjuntos habitacionais que, ao final do século passado, se transformaram em favelas gigantescas. Dito de outro modo, as relações sociais conflitantes fazem com que Manaus agrupe qualidades antagônicas, e que, em grande medida, podem ser interpretadas como signos de lutas sociais.

O casarão da família libanesa em Dois Irmãos (2007) simboliza uma espécie de microcosmo da maneira como os personagens são influenciados pela passagem do tempo e pelas mudanças no espaço físico. Não apenas as mudanças pelas quais passou a cidade de Manaus, mas, sobretudo, no interior das casas, que conheceram tanto a opulência quanto a miséria, tudo seguindo um mesmo fluxo de intensidades. É desse modo que o casarão da família de Halim torna-se uma extensão física das tensões emocionais e dos dramas vividos por seus habitantes.

A casa convida à sensualidade, reforça as qualidades e as diferenças psicológicas dos personagens, cada compartimento auxilia na compreensão das motivações desses personagens. Esta é uma característica dos romances de Milton Hatoum, os narradores são sobreviventes, as pessoas e a própria cidade não são mais do que fantasmagorias do passado, isto é, mesmo Manaus, que sobrevive como o símbolo das ruínas de uma cidade que foi destruída. É nesse sentido que Sophia Beal analisa a influência do espaço urbano em Cinz̧as do Norte:

Cinzas do Norte justapõe o peso e a austeridade das estruturas neoclássicas da belle époque manauara (1880-1910) e a vulnerabilidade e a mutabilidade da Cidade Flutuante de Manaus para refletir sobre a política e as dinâmicas de poder do espaço, relevantes para a história 
de Manaus e para o enredo do romance. O padrão brasileiro de forçar (direta ou indiretamente) seus cidadãos urbanos mais pobres a abandonarem suas residências em locais convenientes e se mudarem para áreas mais afastadas do centro é tão familiar e tão antigo [...] que podemos nos tornar insensíveis a ele. No entanto, somos levados a reconhecer esse tipo de violência espacial no romance de uma forma emocional e sensorial. (BEAL, 2016, p. 73 - grifo da autora)

Em Cinzas do Norte, a arquitetura de Manaus está relacionada de perto, com o embate travado entre Jano e Mundo. Pai e filho representam os dois lados da mesma cidade. Jano Mattoso, o patriarca, é observado pelo narrador Lavo de perto, inclusive é ele quem o leva para visitar sua mansão, um casarão de inspiração britânica e classicista, bem de acordo com o temperamento de Jano Mattoso, um homem conservador e duro. Nessa primeira visita, Lavo não deixa passar em branco a suntuosidade da mansão da família Mattoso:

A sala do palacete, sóbria, com poucos móveis e objetos. Reparei na cristaleira, com vidro também nas laterais, miniaturas de soldados e de máquinas de guerra; ao lado da vitrola, uma estante com livros e discos. Na parede oposta, a fotografia de um casarão de frente para o rio Amazonas. O luxo maior vinha de cima: um estuque antigo com figuras de liras, harpas, cavaletes e pincéis. Fiquei observando o teto até ouvir a voz de Jano: 'É uma pintura de Domenico de Angelis: A glorificação das belas-artes na Amazônia. Imitação do que ele fez para o salão nobre do nosso teatro'. (HATOUM, 2012, pp. 28-29 grifos do autor)

Mundo, por sua vez, na condição de um artista preocupado com os dilemas sociais da cidade, busca, através da transgressão dos valores representados pelo pai, uma arte que dê conta do horror do contraste entre o mundo dos ricos e o mundo dos pobres. A primeira de suas obras, Campo de cruzes, fora inaugurada pouco antes da expulsão da população da cidade flutuante e da invasão denominada ironicamente de Eldorado. A destruição fora completa, a população local fora expulsa de seus barracos, tudo fora destruído pelas forças policiais a mando da prefeitura, pois, como se sabe, aquele espaço daria lugar à chamada Zona Franca de Manaus. Em 1964, havia cerca de 12 mil pessoas vivendo em palafitas das casas flutuantes próximas ao Mercado Central, este cenário ressurge em Cinzas do Norte 
(2012) na cena em que os policiais da prefeitura, sob o comando dos militares destroem um monumento projetado por Mundo e batizado de Campo de cruzes, como relata Lavo, no dia seguinte, em sua visita ao local destruído pela polícia:

A obra do meu amigo, no Novo Eldorado, também terminou em cinzas. $\mathrm{Na}$ foto do jornal, o tronco e os galhos secos de uma única árvore, cheiros de trapos pretos, e uma fileira de cruzes de madeira fincadas nas ruas sem calçada. O título e o subtítulo da reportagem sem dúvida haviam escandalizado o pai: "Campo de cruzes - Filho de magnata inaugura obra de arte macabra". [...].

No dia seguinte bem cedo fui ao Novo Eldorado. O Campo de cruzes havia sido destruído pela polícia na tarde do feriado. A visão das ruínas acentuava a tristeza do lugar. Cruzes de madeira crestadas cobriam um descampado; o tronco de seringueira fora abatido, as raízes arrancadas; galhos secos espetados em trapos queimados pareciam carcaças carbonizadas. Nas ruas de terra, mulheres juntavam pedaços de cruzes para acender um fogareiro. Por volta das oito, os empregados da prefeitura jogaram os destroços na carroceria de um caminhão, deixando apenas a árvore derrubada. (HATOUM, 2012, p. 150)

Enquanto artista e cidadão consciente das injustiças sociais de Manaus, Mundo coloca-se ao lado dos habitantes da cidade flutuante. Sua arte busca representar o sofrimento e as injustiças que ele presencia no local. Trata-se de uma arte que ruma para além de uma mera fruição estética, mas se torna, antes de tudo, potência criativa, ou seja, o fazer artístico de Mundo choca-se com o artificialismo que envolve não apenas o pai, mas também o centro antigo de Manaus.

A austeridade, a imponência, assim como a própria fortuna de Jano, o mundo artificial do ethos europeu desaparecem, enquanto a cidade experimenta novas e contínuas transformações. As cidades latino-americanas - e Manaus é um exemplo bastante peculiar disso - não concebem a memória e a sensorialidade da arquitetura como seus modelos europeus. Ela é autofágica por natureza. Esse pensamento é atestado por Luis Costa Lima (2002, p. 318) a respeito de Manaus e sua complexa relação com a memória: “[...] uma cidade sem raízes, formada por extratos que se dissipam e desaparecem quase sem vestígios. 
Ambiência em que o tempo não forma história ou a história não contém densidade, pois a mudança desconhece estabilidade".

Em Manaus as lembranças que os edifícios históricos evocam estão sempre presentes nos romances de Milton Hatoum; de outro, o esquecimento que o crescimento populacional fora de controle transforma em ruínas o sonho de um cenário de harmonia neoclassicista em plena floresta amazônica. Se aproximando do fim de seu relato, Nael comenta a destruição porque passava a cidade no início dos anos oitenta:

O Café Mocambo fechara, a praça das Acácias estava virando um bazar. A novidade mais triste de todas: o Verônica, lupanar lilás, também fora fechado. Manaus está cheia de estrangeiros. Indianos, coreanos, chineses... O centro virou um formigueiro de gente do interior [...] Tudo está mudando em Manaus”. (HATOUM, 2007, p. 223)

Em várias entrevistas, Milton Hatoum evoca esse passado glorioso de Manaus ${ }^{3}$, que, segundo ele: "Esbanjava um traçado arquitetônico muito europeu, praças interligadas com praças. Toda a infraestrutura urbana havia sido construída pelos ingleses [...]: teatro, os monumentos, os ícones arquitetônicos, os grandes palacetes, a arquitetura neoclássica”.

Conceber o espaço como elemento de inclusão das diferentes camadas da sociedade não é uma característica dessas cidades que crescem vertiginosamente rumo às margens, mais uma vez a imagem recorrente do Oriente é convocada. Manaus cresceu sempre de maneira indiscriminada, destruindo-se e reconstruindo-se ao sabor de interesses voláteis e produzindo cada vez maiores bolsões de miséria e de violência que, ainda hoje, não cessam de expandir-se sem limites. David Harvey (2002, p. 120) observa que as cidades latinoamericanas comumente passam por sucessivas transformações sob a égide da expansão econômica: “[...] luta perpétua em que o capital constrói uma paisagem física adequada à sua própria condição em um momento particular no tempo, só para precisar destruí-la,

\footnotetext{
${ }^{3}$ Hatoum, Milton. "Entrevista. O Amazonas preservou a floresta e destruiu a cidade". Revista de História, Rio de Janeiro, 6 maio 2009. Disponível em: <http://www.revistadehistoria.com.br/secao/entrevista/milton-hatoum>. Acesso em: 10/01/2019.
} 
geralmente, no decurso de uma crise, em um ponto posterior no tempo.”4

Esse modelo de desenvolvimento é típico das regiões marginais do mundo. Tratase de uma noção bastante diferente dos modelos de cidades europeias que, durante os primeiros séculos de colonização, ainda se encontravam muito ligadas aos padrões medievais de controle do espaço urbano:

Os próprios conquistadores que as fundaram foram progressivamente percebendo, no transcurso do século XVI, que haviam se afastado da cidade orgânica medieval em que haviam nascido e crescido para entrar em uma nova distribuição do espaço, que enquadrava um novo modo de vida, que já não era o que haviam conhecido em suas origens peninsulares. Dura e gradualmente, tiveram de se adaptar a um projeto que, como tal, não escondia sua consciência racionalizadora, para a qual não era suficiente organizar os homens dentro de uma repetida paisagem urbana, pois também requeria que fossem moldados com destino a um futuro, sonhado igualmente de forma planificada, em obediência às exigências colonizadoras, administrativas, militares, comerciais e religiosas, que se iriam impondo com crescente rigidez. (RAMA, 2015, p. 21 - grifo do autor)

É preciso notar a importância de uma dupla vida a que foram submetidas praticamente todas as cidades latino-americanas desde suas origens, a saber, uma dinâmica de exploração econômica voltada para a ordem física das cidades, e outra, de caráter simbólico, uma ordem capaz de diferenciar como em outros poucos lugares do mundo as diferenças sociais. Assim, essas cidades cresceram ao sabor do desenvolvimento ou desapareceram com a estagnação e o fracasso exploratório de suas riquezas naturais, ao mesmo tempo, os signos de mundanidade e os signos sensíveis alinham-se na formação da desigualdade social da cidade latino-americana.

Em Dois Irmãos (2007), a desigualdade social se faz perceber no modo como a antiga Manaus que Nael tenta reviver na forma do relato tem de conviver com a nova e moderna Manaus, simbolizada na figura de Yaqub, o irmão que abandonou a família para se tornar um próspero engenheiro em São Paulo e que, durante a ditadura militar se alia aos militares

${ }^{4}$ (Tradução nossa). 
e de certo modo se beneficia do crescimento desordenado da cidade. Nas palavras de Nael, a ganância de Yaqub, seu caráter esquivo e fato de se sentir um estrangeiro mesmo em casa se coadunava com as características de desenraizamento da cidade:

Ele vivia em trânsito, construindo hotéis em vários continentes. Era como se morasse em pátrias provisórias, falasse línguas provisórias e fizesse amizades provisórias. O que se enraizava em cada lugar eram os negócios. Ouvira dizer que Manaus crescera muito, com suas indústrias e seu comércio. Viu a cidade agitada, os painéis luminosos com letreiros em inglês, chinês e japonês. Percebeu que sua intuição não falhara. (HATOUM, 2000, p. 226)

Por um lado é preciso observar a ambivalência entre a ordem física, ou seja, uma qualidade sensível que no caso de Manaus chama a atenção para o fato de que foi construída para representar o ethos europeu frente à ameaça da floresta, por isso sua arquitetura é uma cópia da arquitetura europeia da Belle Epoque ${ }^{5}$, por outro lado, não é difícil observar que a cidade se destrói quase aleatoriamente, nesse sentido, a construção de novos prédios não afetam a memória e a arquitetura dos tempos áureos. Não se pode deixar de evocar a força dos signos de mundanidade, ou seja, a conflituosa rede de relações sociais e o controle do poder que se deixa ver nos rastros na arquitetura de Manaus. De acordo com Sophia Beal, a importância do espaço na configuração dos romances de Milton Hatoum é tão importante quanto o aspecto memorialístico:

Um dos mestres de fazer-nos enxergar novamente espaços é Milton Hatoum. Seu livro Cinzas do Norte, de 2005, está entre os mais aclamados romances brasileiros contemporâneos. Enquanto a maior parte da crítica literária sobre a obra de Hatoum centra-se na memória, eu argumento que o espaço, particularmente as dinâmicas de poder em torno de quem o controla e quem lhe atribui sentido, é tão importante para sua ficção. A cidade de Manaus e as transformações destrutivas de espaço que ali ocorreram durante a ditadura militar brasileira assombram o texto. A Manaus do romance não é um receptáculo neutro e estático em que a ação transpira. Em vez disso, a cidade exige a nossa atenção e resiste às nossas expectativas, fazendo-nos refletir de modo mais geral sobre quem controla o traçado de uma cidade e quais tipos de projetos seriam mais benéficos

5 (Grifo nosso). 
para a subsistência dos moradores. (BEAL, 2016, p. 72)

A cidade não tem identidade. Seja pelo recurso incessante e fragmentado do apelo à memória de narradores marginalizados; de retalhos de imagens ligadas à infância dos narradores, ou mesmo os momentos culminantes das narrativas em ambientes domésticos, tratando sempre o problema da vida em grupos heterogêneos de patrões e empregados, de filhos autênticos e agregados, ou ainda das várias ondas de construção, destruição e reconstrução da cidade. Pode-se afirmar que todas as séries de dramas sociais ou familiares representam a necessidade de adaptar-se ao espaço liminar dessa cidade nem europeia nem indígena.

\section{Considerações finais}

Se nos séculos anteriores havia sido fundada como um entreposto militar e que depois veio a se chamar forte de São José do Rio Negro, sabe-se que apenas no século XVIII passou a chamar-se "Manaos" em homenagem à tribo dos Manaós que vivia na região antes da chegada dos conquistadores espanhóis e portugueses. Esta é a época em que todas as grandes cidades latino-americanas já haviam sido fundadas e experimentado a organização e a rigidez simétrica copiadas dos centros urbanos europeus, como sustenta Ángel Rama:

Uma correspondente à ordem física, que, por sensível, material, está submetida aos vaivéns da construção e da destruição, da instauração e da renovação, mas sobretudo aos impulsos da invenção circunstancial de indivíduos e grupos, segundo seu momento e situação. Acima dela, encontra-se a segunda, correspondente à ordem dos signos que atuam simbolicamente, desde antes de qualquer realização, e também durante e depois, pois dispõem de uma inalterabilidade a que pouco convergem os avatares materiais. Antes de ser uma realidade de ruas, casas e praças, que só podem existir (e ainda assim gradualmente) no transcurso do tempo histórico, as cidades emergiam já completas por um ponto de inteligência nas normas que as teorizavam, nos atos fundacionais que as instituíam, nos planejamentos que as desenhavam idealmente. (RAMA, 2015, p. 29) 
Embora a disciplina hierárquica dessa transmutação se desse através de diferentes tentativas de fazer com que a região se integrasse ao desenvolvimento econômico do resto do país ou fosse, também, pela complexa relação de hibridização de culturas dominantes sobre culturas dominadas resultando nas diferentes redes diaspóricas e, sobretudo, no resultado dessas construções socioculturais, o certo é que quase sempre a construção identitária da região tenha sido expressa na forma de uma violência levada ao paroxismo, na verdade, uma reação que a interação forçada evoca.

\title{
THE SURVIVING OF THE SIGNS, THE INVOLUNTARY MEMORY OF THE STRANGER AND THE URBAN SPACE IN RUINS: T
}

\begin{abstract}
This article has the intention to understand some qualities and pluralities of signs issued on the three first novels of Milton Hatoum, Relato de um certo Oriente (2014), Dois irmãos, (2007), Órfãos do eldorado, (2008), Cinzas do Norte. (2012). Departing from the theorical assumptions by Gilles Deleuze and Félix Guattari about the way of interpretation of the memories signs: like the signs of love, sensibilities, mundanities and art, this last is responsible for gathering the other forms of art. The goal is try to become evidente how the modulations of intensitie's productions and individuation not segmented in binarysm give the chance to understand that in Milton Hatoum `s Works the theme is not the memory, but the surviving of traumatic images, the symptons of violence, the ghosts and the surviving of the signs. The signs of love, for example, besides the fact that they are conected to the signs of art, they give us the chance to undestand how survive incestuous forms of love, recurrent theme in Milton Hatoum. Finally, these new forms of individuation and production of subjectivity that not return is a complex game of ruins on the form of memories, but, in the words of Gilles Deleuze, in practices of production of signs that affect and let to be affect for others plural subjectivities. The result is the fact that the capture of these signs in Milton Hatoum 's novels has not the power to go beyond of what immersed in the signs repeat, repelling and dialogues between themselves.
\end{abstract}

KEYWORDS: Signs; Symptons; Ghosts; Memories; Amazon.

\section{REFERÊNCIAS}

AGAMBEN, Giorgio. O bomem sem conteúdo. Tradução, notas e prefácio de Cláudio Oliveira. $2^{\circ}$ edição. Belo Horizonte: Boitempo, 2013.

. Homo Sacer: o poder soberano e a vida nua I. Tradução de Henrique Burigo. Belo Horizonte: Editora UFMG, 2014.

. Bartleby, ou da contingência. Tradução de Vinícius Honesko. Belo Horizonte: Autêntica, 2015. 
BEAL, S. Espaços movediços e conflitantes na Manaus de Milton Hatoum. Teresa revista de Literatura Brasileira [17]; São Paulo, 2016, p. 71-86.

BERGSON, H. Matéria e memória. Tradução de Paulo Neves. $2^{\circ}$ ed. São Paulo: Martins Fontes, 1999.

BLANCHOT, M. Uma voz vinda de outro lugar. Tradução de Adriana Lisboa. Rio de Janeiro: Rocco, 2011.

BIRMAN, Daniela. Entre-narrar: Relatos da fronteira em Milton Hatoum. 2007. Tese de Doutorado em Literatura Comparada apresentada ao Programa de Pós-Graduação em Ciência da Literatura, Faculdade de Letras, Universidade Federal do Rio de Janeiro. Data de acesso: $12 / 09 / 2015$.

BOOTH, Wayne. A retórica da Fiç̧ão. Tradução de Maria Teresa H. Guerreiro. Lisboa: Arcádia, 1980.

BULFINCH, T. O livro da mitologia: história de deuses e heróis. A idade da fábula. Tradução de Luciano Alves Meira. São Paulo: Martin Claret, 2006.

CASTRO, Edgardo. Introdução a Giorgio Agamben: Uma arqueologia da potência. Tradução de Beatriz de Almeida Magalhães. Belo Horizonte: Editora Autêntica, 2016.

CONRAD, Joseph. No coração das trevas. Tradução de José Roberto O Shea. São Paulo: Editora Abril Cultural, 2010.

COSTA LIMA, L. O redemunho do horror: as margens do ocidente. São Paulo: Planeta do Brasil, 2003.

CURY, M. Topografias da ficção de Milton Hatoum. In: RAVETTI, G, CURY, M, ÁVILA, M. (Orgs.). Topografias da cultura: representação, espaço e memória. Belo Horizonte: UFMG, 2009.

CURY, M. Z. F. Entre o rio e o cedro: imigração e memória. In: CRISTO, Maria da Luz Pinheiro de (Org.). Arquitetura da Memória: ensaios sobre os romances Relato de um certo Oriente, Dois Irmãos e Cinzas do Norte de Milton Hatoum. Manaus: Valer, Oficina das Artes, 2007.

DELEUZE, Gilles. Proust e os signos. Tradução de Antônio Piquet e Roberto Machado. Rio de Janeiro: Forense Universitária, 2003.

. Kafkea: por uma literatura menor. Tradução de Júlio Castañon Guimarães. Rio de Janeiro: Editora Autêntica, 2014.

.; GUATTARI, F. Mil Platôs: capitalismo e esquizofrenia. 5 vols. Tradução de Suely

Rolnik. São Paulo: Editora 34, 2012.

FOUCAULT, M. Vigiar e punir nascimento da prisão. Tradução de Raquel Ramalhete.

Petrópolis, Rio de Janeiro: Vozes, 1987. 
HARVEY, David. 2002. A condição pós-moderna. Tradução de Adail Ubirajara Sobral e Maria Stela Gonçalves. São Paulo: Edições Loyola, 2002.

HATOUM, Milton. Relato de um certo Oriente. 2. ed. São Paulo: Companhia das Letras, 2014.

HATOUM, Milton. Dois irmãos. São Paulo: Companhia das Letras, 2007.

Órfãos do eldorado. São Paulo: Companhia das Letras, 2008.

Cinzas do Norte. São Paulo: Companhia das Letras, 2012.

- Treze perguntas para Milton Hatoum. Magma / Departamento de Teoria Literária e Literatura Comparada. FFLCH/USP. São Paulo: Editora da USP, 2000.

HOLLANDA, Lourival. A narrativa do espólio em Milton Hatoum. In: Topografias da cultura: representação, espaço e memória. RAVETTI, G, CURY, M, ÁVILA, M. (Orgs.). Belo Horizonte: UFMG, 2009.

MACHADO, R. Deleure, a arte e a filosofia. $2^{\circ}$ Ed. Rio de Janeiro: Jorge Zahar Editora, 2010.

NASCIMENTO, E. Derrida e a literatura: "notas" de literatura e filosofia nos textos da desconstrução. 3 ed. São Paulo: É Realizações, 2015.

PROUST, M. Em busca do tempo perdido. Tradução de Fernando Py. Rio de Janeiro: Nova Fronteira, 2016.

RAMA, A. A cidade das letras. Tradução de Emir Sader. São Paulo: Boitempo, 2015.

RICOER, Paul. A memória, a história, o esquecimento. Tradução de Alain François et al. Campinas, São Paulo: Editora Unicamp, 2014.

ROCHA, A. Milton Hatoum: Ocidente esconde cultura árabe. 16 ago. 2006. Disponível em: <www.anba.com.br/orientese.php?id=61>. Data de acesso: 12/08/2016.

WILLEMART, P. Proust, poeta e psicanalista. Tradução de Peter Pal Pelbart. São Paulo: Ateliê Editorial, 2000.

WOOD, J. Como funciona a fiç̧ão. Tradução de Denise Bottmann. São Paulo: Cosac Naify, 2014.

Recebido em: 26/02/2019.

Aprovado em: 30/5/2019. 